\title{
PENINGKATAN PERFORMANSI PROSESOR DLX DENGAN METODE PIPELINE
}

\author{
Maman Abdurohman \\ Jurusan Teknik Informatika Sekolah Tinggi Teknologi Telkom, Bandung \\ mma@stttelkom.ac.id
}

\begin{abstract}
Abstrak
Prosesor DLX adalah sebuah prosesor berbasis RISC (Reduced Instruction Set Computer) yang dirancang sebagai prosesor tujuan umum (general purpose processor). Prosesor ini mempunyai arsitektur load-store dengan panjang semua instruksinya 32 bit. Setiap instruksi dieksekusi dalam beberapa siklus waktu (cycletime). Secara umum time cycle yang digunakan sebanyak lima tahap yang terdiri dari tahap-tahap : Instruction Fetch (IF), Instruction Decode (ID), Execute (EX), Memory Access (MEM), dan Write Back (WB). Kelima tahap ini dikerjakan secara berurutan [2]. Sebagai prosesor multicycle, DLX mempunyai peluang untuk meningkatkan kinerjanya yang diukur dengan kecepatan proses yang dinyatkan sebagai waktu CPU (CPU time). Peningkatan kinerja prosesor DLX dapat diterapkan dengan menggunakan teknik pipeline. Pada jurnal ini telah dianalisis peningkatan performansi prosesor DLX dengan menggunakan teknik pipeline. Uji coba dilakukan terhadap beberapa program aplikasi yang dieksekusi dengan menggunakan teknik pipeline dan tanpa menggunakan teknik pipeline. Secara umum terjadi peningkatan kecepatan pada setiap kumpulan instruksi yang dianalisis. Proses pengujian dilakukan dengan menggunakan simulator windlx yang merupakan simulator prosesor DLX.
\end{abstract}

Kata kunci : Prosesor DLX, RISC, general purpose processor, CPU, Pipeline, windlx

\section{Abstract}

DLX processor is a RISC based processor that designed as general purpose processor. Its named loadstore processor architecture with 32 bit all instruction long. Each instruction is executed in multicycle time. The stages, generally, used is constist of five process such as Instruction Fetch (IF), Instruction Decode (ID), Execute (EX), Memory Access (MEM), dan Write Back (WB), respectively [2]. DLX has an opprotunity, due to its multycycles processes, to increase its performance, measured in CPU time, using pipeline technique. This paper tells about increasing performance analysis of DLX processor by implementing pipeline technique. Many instructions are tested with and without pipeline technique. These results show, in general, there is increasing rate of process after pipeline implementation. Windlx simulator is used to test many programs in DLX assembly.

Keywords: DLX processor, RISC, general purpose processor, CPU, Pipeline, windlx

\section{Pendahuluan}

Prosesor DLX merupakan prosesor dengan arsitektur RISC yang dirancang sebagai general purpose processor. DLX memiliki panjang instruksi 32 bit dengan tiga tipe instruksi, yaitu R-type, I-type dan J-type. Setiap instruksi dieksekusi melalui lima tahap. Kelima proses tersebut dilakukan dalam lima siklus waktu (cycle time), sehingga masing-masing proses saling bebas satu dengan lainnya. Ketika satu proses sedang diselesaikan, proses yang lainnya sedang menunggu. Demikian juga dengan instruksinya, dikerjakan satu per satu.

Penyelesaian suatu instruksi dalam lima siklus merupakan proses yang tidak efisien, karena pada saat yang bersamaan juga terdapat proses dan instruksi yang sedang menunggu. Menambahkan mekanisme untuk mengeksekusi instruksi secara bersamaan, dengan tidak ada tahapan yang berhenti, dipandang dapat meningkatkan kinerja prosesor tersebut. Peningkatan kinerja yang dimaksud adalah semakin sedikitnya kebutuhan waktu untuk menyelesaikan suatu program yang terdiri dari banyak instruksi.

Metode pengerjaan instruksi secara bersamaan pada proses yang berbeda disebut teknik pipeline. Teknik ini ditujukan untuk meningkatkan kinerja prosesor. Kinerja yang baik berbanding terbalik dengan waktu proses. Semakin kecil waktu proses, semakin baiklah kinerjanya.

Rancangan awal prosesor DLX tidak menggunakan metode pipeline, dimana setiap instruksi akan dikerjakan satu persatu yang masingmasing memerlukan 5 waktu siklus (cycletime). Untuk mengetahui seberapa efektif penerapan teknik pipeline terhadap peningkatan kinerja porsesor DLX, perlu dilakukan penelitian lebih lanjut tentang penerapan teknik ini.

Pada jurnal ini dipaparkan penerapan metode pipeline dan analisis teknik penerapannya pada prosesor DLX dalam meningkatkan kinerja prosesor tersebut. Analisis dilakukan dengan membandingkan kinerja prosesor DLX dengan pipeline terhadap tanpa pipeline. 
Pengujian peningkatan performansi prosesor idealnya dilakukan dengan menerapkan langsung pada perangkat keras prosesor DLX. Karena saat ini belum ada representasi prosesor DLX yang sempurna, maka uji coba dilakukan pada simulator DLX yaitu windlx.

\section{Prosesor DLX (Delux)}

\subsection{Jalur Data dan Kendali}

Prosesor DLX menggunakan arsitektur ambilsimpan (load-store) dengan lima tahap pipeline untuk menyelesaikan instruksi. Kelima tahap tersebut adalah: Pengambilan Instruksi - Instruction Fetch (IF), Penerjemahan Kode - Instruction Decode (ID), Eksekusi - Execute (EX), Akses Memori - Memory Access (MEM), dan Menulis Balik - Write Back (WB). Panjang semua instruksi DLX adalah 32 bit. Dengan rancangan ini, maka proses fetch instruksi dari memori akan lebih mudah. Pengambilan instruksi ini dilakukan dengan membaca 4-byte data dalam memory.

Arsitektur prosesor DLX terdiri dari 5 komponen utama, sebagaimana diperlihatkan pada Gambar 1, yaitu terdiri dari:

a. PC (Program Counter) : register yang berfungsi menampung nilai yang digunakan untuk menunjuk alamat instruksi yang akan dieksekusi.

b. Memori Instruksi : Memori tempat menyimpan sejumlah instruksi yang akan dijalankan.

c. Register : Kumpulan Register 32 bit tempat menyimpan nilai sementara.

d. ALU (Arithmatic and Logical Unit) : tempat dilakukannya operasi aritmetik dan logic.

e. Memori Data : Memori untuk menyimpan data.

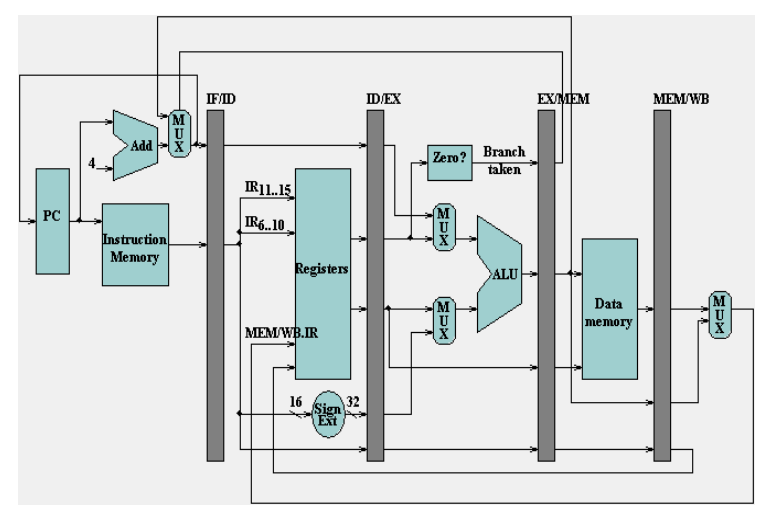

Gambar 1. Data Path Prosesor DLX

Prosesor DLX memiliki 32 buah register dengan masing-masing panjangnya 32 bit. Dua buah register mempunyai fungsi khusus, yaitu register 0 selalu bernilai nol. Register ini digunakan sebagai operand sumber jika memerlukan nilai nol. Register 31 disediakan oleh suatu instruksi DLX. DLX juga memiliki program counter dengan panjang 32 bit.

Salah satu ciri arsitektur RISC adalah memiliki panjang instruksi yang sama. DLX memiliki panjang instruksi 32 bit dengan 5 tahap pipeline yaitu : IF, ID, EX, MEM, dan WB.

Tahapan WB (Write Back) menyediakan saluran bagi DLX sehingga dapat menyimpan kembali register untuk tahap eksekusi (EX). Hal ini akan mempercepat pelaksanaan operasi register-keregister oleh unit logic dan aritmetik yang berada dalam tahap eksekusi.

Operasi register-ke-register meningkatkan keseluruhan kecepatan saluran dimana tahapan tidak diperlambat oleh operasi fetch/write memori. Hal ini sangat penting dalam peningkatan kecepatan yang merupakan salah satu bagian penting arsitektur RISC. Arsitektur ini menuntut agar seluruh instruksi harus selesai dalam satu siklus yang sempurna.

Penjelasan rinci kelima tahap tersebut adalah sebagai berikut :

a. Siklus fetch instruksi (IF)

$$
I R \leftarrow M E M[P C]
$$$$
\mathrm{PC} \leftarrow \mathrm{PC}+4
$$

b. Siklus decode/Register Fetch (ID)

$$
\begin{aligned}
& A \leftarrow \operatorname{Regs}[\text { IR 6..10] } \\
& B \leftarrow \text { Regs [IR 11..15] }
\end{aligned}
$$$$
I m m \leftarrow\left(\left(I_{16}\right)^{16} \text { \#\# } I R_{16 . .31}\right)
$$

c. Siklus eksekusi (EX)

Mengacu memori : ALUOutput $\leftarrow A+I m m$

Instruksi ALU register-register : ALUOutput $\leftarrow$ A op B

Instruksi ALU register-immediate : ALUOutput $\leftarrow$ A op Imm

Pencabangan : ALUOutput $\leftarrow$ NPC + Imm Cond $\leftarrow$ (A op 0$)$

d. Siklus akses memori/pencabangan (MEM)

Mengacu memori : LMD $\leftarrow$ Mem [ALUOutput

Pencabangan : if (cond) $\leftarrow$ ALUOutput else $\mathrm{PC} \leftarrow$ NPC

e. Siklus tulis-balik (WB)

Instruksi ALU register-register : Regs [IR 6..20] $\leftarrow$ ALUOutput

Instruksi ALU register-immediate : Regs [IR 11..15] $\leftarrow$ ALUOutput

Instruksi Load : Regs $[$ IR $11 . .15] \leftarrow$ LMD

\subsection{Implementasi Dasar DLX}

Setiap instruksi DLX dapat diimplementasikan paling banyak dalam 5 siklus clock. Kelima siklus clock tersebut adalah sebagai berikut :

a. Siklus pengambilan (fetch) instruksi (IF):

$$
\begin{aligned}
& \mathrm{IR} \leftarrow \mathrm{Mem}[\mathrm{PC}] \\
& \mathrm{NPC} \leftarrow \mathrm{PC}+4
\end{aligned}
$$

Operasi: mengeluarkan nilai PC dan mengambil isi memori pada alamat PC di simpan ke dalam register instruksi (IR), nilai PC ditambah 4 untuk menunjuk pada instruksi selanjutnya. IR digunakan untuk menyimpan instruksi yang diperlukan pada siklus clock selanjutnya; begitu juga register NPC digunakan untuk menyimpan nilai PC berikutnya. 
b. Siklus decode instruksi (ID), pengambilan isi register:

$$
\begin{aligned}
& A \leftarrow \operatorname{Regs}[\text { IR6 .. 10]; } \\
& B \leftarrow \text { Regs [IR11..15]; } \\
& \text { Imm } \leftarrow((\text { IR16) 16\#\#IR16..31) }
\end{aligned}
$$

Operasi: decode instruksi dan mengakses file register untuk membaca register. Keluaran dari register-register tujuan-umum disimpan dalam register sementara (A dan B) untuk digunakan pada siklus selanjutnya. 16 bit bawah pada IR juga adalah sign-extended dan disimpan ke dalam register sementara Imm, untuk digunakan pada siklus berikutnya.

Proses decode dilakukan bersamaan dengan pembacaan register. Hal ini dimungkinkan, karena field-nya berada pada lokasi yang tetap dalam format instruksi DLX. Teknik ini dinamakan decode field-tetap (fixed-field decoding). Dengan catatan, kita mungkin membaca register yang tidak digunakan, yang tidak membantu dan tidak merugikan juga. Karena porsi immediate setiap instruksi DLX berada pada tempat yang sama, sign-extented immediate juga dihitung selama siklus ini yang mungkin diperlukan pada siklus berikutnya.

c. Siklus eksekusi (EX), alamat efektif:

ALU melaksanakan salah satu jenis fungsi dari 4 fungsi operasi dengan operand berasal dari siklus sebelumnya. Operasi yang dilaksanakan oleh ALU ditentukan oleh tipe intstruksinya :

- Mengacu pada memori

$$
\text { ALUOutput } \leftarrow \text { A }+ \text { Imm; }
$$

Operasi: ALU menjumlahkan operandoperandnya untuk mendapatkan alamat efektif dan menempatkan hasilnya ke dalam register ALUOutput.

- Instruksi register-register ALUOutput $\leftarrow$ A op B;

Operasi: ALU melaksanakan operasi yang ditentukan oleh opcode terhadap nilai register A dan nilai register B. Hasilnya disimpan sementara di register ALUOutput.

- Instruksi register-immediate

$$
\text { ALUOutput } \leftarrow \text { A op Imm; }
$$

Operasi: ALU melaksanakan operasi yang ditentukan oleh opcode terhadap nilai register A dan nilai pada register Imm. Hasilnya disimpan sementara di register ALUOutput.

\section{Pencabangan}

$$
\begin{aligned}
& \text { ALUOutput } \leftarrow \text { NPC }+ \text { Imm; } \\
& \text { Cond } \leftarrow(A \text { op } 0)
\end{aligned}
$$

Operasi: ALU menjumlahkan NPC dengan nilai sign-extended immediate dalam register Imm untuk menghasilkan alamat tujuan pencabangan. Register A, yang telah dibaca pada siklus sebelumnya, diperiksa untuk menentukan apakah terjadi pencabangan. Operasi perbandingan op adalah operator relasi yang ditentukan oleh opcode pencabangan, contoh op sama dengan "==" untuk instruksi BEQZ.
DLX disebut arsitektur load-store artinya bahwa siklus alamat efektif dan eksekusi dapat dikombinasikan ke dalam satu siklus clock, karena tidak ada instruksi yang secara bersamaan menghitung alamat data, menghitung alamat tujuan instruksi, dan melaksanakan operasi pada data.

d. Siklus akses memori (MEM), penyelesaian pencabangan:

Instruksi DLX yang aktif pada siklus ini adalah instruksi-instruksi load, store dan branche.

- Mengacu pada memori :

$$
\begin{aligned}
& \text { LMD } \leftarrow \text { Mem [ALUOutput] atau } \\
& \text { Mem[ALUOutput] } \leftarrow B
\end{aligned}
$$

Operasi: akses memori jika diperlukan. Jika instruksi di load, data dari memori ditempatkan pada register LMD (load memory data), jika instruksinya store maka data dari register B akan disimpan dalam memori.

- Pencabangan:

$$
\begin{aligned}
& \text { If (cond) } \mathrm{PC} \leftarrow \text { ALUOutput } \\
& \text { else } \mathrm{PC} \leftarrow \mathrm{NPC}
\end{aligned}
$$

Operasi: untuk jenis instruksi pencabangan, maka nilai PC ditimpa dengan alamat tujuan pencabangan yang ada pada register ALUOutput, jika tidak maka nilai PC digantikan nilai register NPC.

e. Siklus tulis-balik (WB)

- Instruksi Register-Register Regs[IR16..20] $\leftarrow$ ALUOutput;

- Instruksi Register-Immediate Regs[IR11..15] $\leftarrow$ ALUOutput;

- Instruksi Load Regs [IR11..15] $\leftarrow$ LMD;

Operasi: hasil akhir dari instruksi dituliskan ke dalam file register, baik yang berasal dari sistem memori (pada LMD) atau dari ALU (pada ALUOutput). Register tujuan juga berada pada salah satu posisi field tergantung opcode.

Pada akhir setiap siklus clock, setiap nilai yang dihitung selama siklus clock tersebut dan diperlukan pada siklus clock berikutnya (baik untuk instruksi sekarang atau berikutnya) ditulis ke dalam perangkat penyimpan, yang mungkin berupa memori, register tujuan-umum, PC atau register sementara (seperti LMD, Imm, A, B, IR, NPC, ALUOutput atau Cond). Register sementara menyimpan nilai atnara siklus clock untuk satu instruksi, sementara elemen penyimpan lainnya adalah menyimpan nilai untuk instruksi berikutnya.

Pada implementasi ini, instruksi pencabangan memerlukan empat siklus dan semua instruksi lain memerlukan lima siklus.

\subsection{Format Instruksi}

Dalam DLX terdapat tiga buah format instruksi yaitu: tipe-R, tipe-I dan tipe-J. Semua format instruksi dibedakan oleh kode operasinya (operation 
code - opcode). Informasi lain pada setiap format juga berbeda-beda. Instruksi tipe-R (register) membutuhkan dua register sumber dan satu register tujuan. Instruksi tipe-I (immediate) membutuhkan satu buah register sumber, satu buah register tujuan dan nilai 16-bit. Instruksi tipe-J (jump) terdiri dari opcode dan 26 bit operand. Format instruksi DLX dijelaskan pada Tabel 1. Set instruksi pada Prosesor DLX dapat dilihat dalam daftar pada Lampiran.

Tabel 1. Format Instruksi DLX

\begin{tabular}{|l|cc|cc|cc|cc|cc|cc|}
\hline \multirow{2}{*}{ Format } & \multicolumn{10}{|c|}{ Bit } \\
\cline { 2 - 10 } & 31 & 26 & 25 & 21 & 20 & 16 & 15 & 11 & 10 & 6 & 5 & 0 \\
\hline Tipe-R & $0 \times 0$ & Rs1 & Rs2 & Rt & no & Op \\
\hline Tipe-I & Op & Rs1 & Rt & \multicolumn{7}{|c|}{ immediate } \\
\hline Tipe-J & Op & \multicolumn{8}{|c|}{ Nilai } \\
\hline
\end{tabular}

\section{Penerapan Teknik Pipeline Pada Prosesor DLX dan Kendalanya}

\subsection{Definisi}

Pipelining adalah teknik implementasi dengan beberapa instruksi dieksekusi dalam waktu yang bersamaan. Saat ini, pipelining merupakan teknik implementasi kunci yang digunakan untuk meningkatkan kecepatan CPU. Pipeline mirip dengan jalur perakitan. Pada jalur perakitan mobil, terdapat beberapa tahap, masing-masing tahap memberikan kontribusi bagi konstruksi mobil. Setiap tahap beroperasi secara paralel dengan tahap lain untuk mobil yang berbeda. Dalam pipeline komputer, setiap tahap dalam pipeline menyelesaikan satu bagian instruksi. Masing-masing tahap ini dinamakan tahap pipe atau segmen pipe. Tahapan-tahapan terhubung satu dengan berikutnya untuk melakukan satu rangkaian pekerjaan.

Throughput didefinisikan sebagai jumlah instruksi yang keluar dari pipeline per satuan waktu. Karena pipe stage berkaitan satu sama lain, seluruh tahapan harus siap untuk memproses pada waktu bersamaan. Waktu yang diperlukan antara perpindahan instruksi satu tahap pipeline disebut siklus mesin. Karena semua tahap bekerja simultan, maka panjang siklus mesin ditentukan oleh waktu yang diperlukan oleh tahap pipe yang paling lambat. Dalam komputer, siklus mesin ini biasanya satu siklus clock (kadang-kadang dua atau lebih), walaupun clock mungkin mempunyai banyak fase.

Tujuan perancang pipeline adalah agar panjang setiap tahap pipeline seimbang. Jika tahap-tahap tersebut seimbang secara sempurna, maka waktu per instruksi pada mesin dengan pipeline - asumsi kondisi ideal - sama dengan: pembagian Waktu per instruksi pada mesin tanpa pipeline oleh Jumlah tahap pipe. Dengan kondisi ini, peningkatan kecepatan sama dengan jumlah tahap pipe. Biasanya, bagaimanapun, tahapan-tahapan tidak akan seimbang secara sempurna; lebih lanjutnya pipeline akan melibatkan overhead.
Pipelining menghasilkan pengurangan rata-rata waktu eksekusi per instruksi. Pengurangan ini akan terlihat sebagai penurunan jumlah siklus clock per instruksi (CPI), sebagai penurunan waktu siklus clock atau kombinasinya. Jika titik awalnya mesin yang mengambil banyak siklus clock per instruksi, maka pipelining biasanya dilihat sebagai pengurangan CPI. Jika titik awalnya adalah mesin yang mengambil satu siklus clock per instruksi, maka pipelining menurunkan waktu siklus clock.

\subsection{Pipeline pada prosesor DLX}

Pipeline dapat dibuat pada jalur data DLX dengan sedikit perubahan dengan memulai instruksi baru pada setiap siklus clock. Setiap siklus clock dari bagian sebelumnya menjadi pipe stage salah satu siklus dalam pipeline. Pola eksekusinya diperlihatkan seperti pada Tabel 2.

Tabel 2. Proses Pipeline

\begin{tabular}{|l|c|c|c|c|c|c|c|}
\hline Instruksi & 1 & 2 & 3 & 4 & 5 & 6 & 7 \\
\hline Ins i & IF & ID & EX & MEM & WB & WB & WB \\
Ins $i+1$ & & IF & ID & EX & MEM & MEM & \\
Ins $i+2$ & & & IF & ID & EX & & \\
\hline
\end{tabular}

Setiap instruksi mengambil lima siklus clock sampai selesai. Selama setiap siklus clock, perangkat keras menginisiasi satu instruksi baru dan mengeksekusi bagian dari lima instruksi berbeda.

Pada kenyataannya pipeline tidak sesederhana kondisi di atas. Ada beberapa perintah yang tidak bisa dijalankan secara paralel karena ada sumber daya yang salin tergantung misalnya sehingga satu instruksi tidak dapat berjalan sebelum instruksi hasil instruksi sebelumnya diperoleh. Ini salah satu masalah yang harus diselesaikan agar tujuan dari pipeline tercapai.

Untuk mengetahui lebih rinci permasalahannya, harus diketahui apa yang terjadi pada setiap siklus clock mesin dan harus dipastikan bahwa tidak dilakukan dua operasi yang berbeda dengan sumber datapath yang sama pada siklus clock yang sama. Contoh, sebuah ALU tidak dapat diminta untuk menghitung alamat efektif dan melakukan operasi pengurangan secara bersamaan. Jadi, harus dipastikan tumpang tindih instruksi dalam pipeline tidak menyebabkan terjadinya konflik seperti itu.

\subsection{Hambatan Pipeline}

Terdapat situasi, disebut hazard (resiko), yang mencegah instruksi berikutnya dalam rangkaian instruksi eksekusi selama siklus clock yang ditandainya. Ada tiga kelas hazard yang menurunkan kinerja kecepatan ideal pipelining, yaitu:

a. Hazard struktur akibat dari konflik sumber daya pada saat perangkat keras tidak dapat mendukung semua kemungkinan kombinasi instruksi dalam eksekusi yang simultan. 
b. Hazard data yang timbul pada saat instruksi tergantung pada hasil instruksi sebelumnya.

c. Hazard kendali akibat pipelining pencabangan dan instruksi lain yang mengubah PC.

Hazard dalam pipeline mengakibatkan pipeline harus melakukan stall. Dalam mengatasi hazard serting kali memerlukan beberapa instruksi dalam pipeline diizinkan untuk diproses sementara instruksi lain menunggu (delay). Pada saat sebuah instruksi di-stall, semua instruksi yang keluar sesudah instruksi tersebut di stall juga. Instruksi yang muncul sebelum instruksi yang distall harus terus dipipeline. Hasilnya, tidak instruksi baru yang difetch selama stall.

\section{Kinerja Prosesor DLX dengan Pipeline}

\subsection{Skenario Pengujian}

Pengujian dilakukan dengan menggunakan beberapa aplikasi yaitu :

- gccdlx: cross compiler DLX pada gcc. Fungsinya meng-compile sumber dalam bahasa *.c atau *.cpp ke dalam bahasa assembly DLX.

- dlxcc: cross compiler DLX untuk file c atau cpp.

- dlxsim: simulator DLX yang meng-assembly bahasa tingkat rendah dalam bahasa assembly DLX ke dalam bahasa mesin untuk dijalankan.

- windlx: simulator DLX dalam window yang berfungsi untuk menjalankan aplikasi dalam bahasa assembly DLX kemudian ditampilkan berbagai hasil pengerjaan file tersebut [1].

Pengujian dimulai dengan melihat program dalam bahasa c atau cpp kemudian dicompile menjadi bahasa assembly DLX dengan menggunakan gccdlx atau dlxcc [3]. Output dari gccdlx atau dlxcc dijalankan dalam windlx[4], sehingga jumlah instruksi yang dieksekusi dapat diketahui dan berapa banyak cycle time yang diperlukan setelah diterapkannya pipeline.

Pengujian di atas kemudian dibandingkan dengan menjalankan instruksi tanpa pipeline, setiap instruksi dijalankan dalam 5 siklus clock.

\subsection{Metode Pengujian}

Pengujian dilakukan pada beberapa program untuk mengukur peningkatan kecepatan (speedup) setelah menggunakan pipeline. Program uji terdiri lima buah jenis aplikasi berbeda yang terdiri dari: operasi array, data hazard, bilangan prima, penjumlahan nilai skalar dan memori. Masingmasing aplikasi akan dijalankan dengan menggunakan metoda pipeline untuk diukur total siklus yang diperlukan sampai program selesai.

Hasil pengujian ini akan dibandingkan dengan banyaknya siklus yang diperlukan tanpa pipeline. Dengan membandingkan keduanya akan diperoleh peningkatan kecepatan (Speedup). Semakin tinggi nilai speedup berarti pipeline semakin efektif pada jenis program tersebut.

\subsection{Program Aplikasi Sebagai Materi Uji}

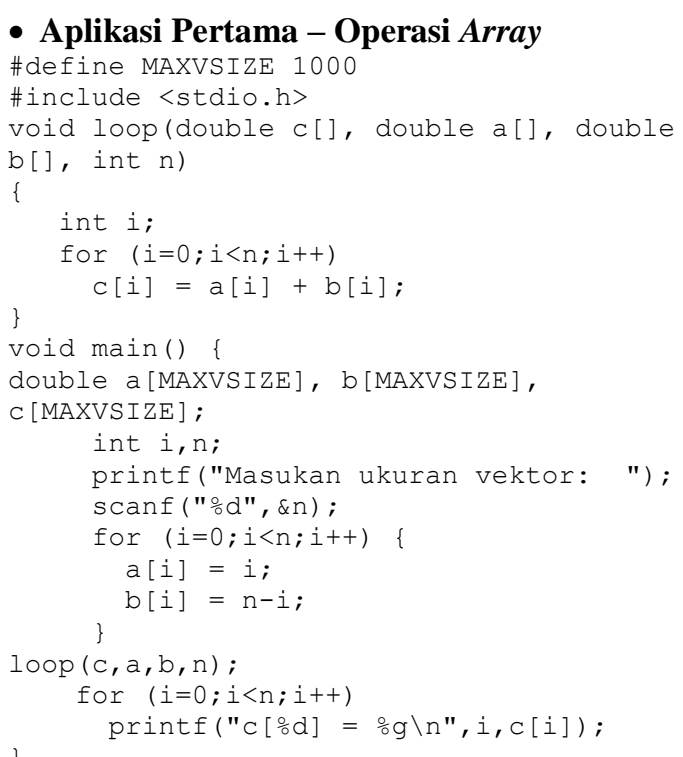

Data setelah dcompile oleh dlxcc

- data

Size: .word 5

A: .double $\quad 1.0,2.0,3.0,4.0,5.0$

B:.double $\quad 5.0,4.0,3.0,2.0,1.0$

C:.double $\quad 0.0,0.0,0.0,0.0,0.0$

. text

-global main

main:

lw $\quad r 2, \operatorname{size}(r 0)$

addi $\quad r 1, r 0,0 \quad ; r 1=i=0$

Loop: seq $r 3, r 1, r 2$

bnez r3, Exit

sll r4,r1,3 ; r4 $=8 * i$

ld $\mathrm{f2}, \mathrm{A}(\mathrm{r}) \quad$; load $\mathrm{A}[\mathrm{i}]$

ld $\mathrm{f} 4, \mathrm{~B}(\mathrm{r} 4)$; load B[i]

ddd

sd $\quad \mathrm{C}(\mathrm{r} 4), \mathrm{fO} \quad$; store $\mathrm{C}[\mathrm{i}]$

addi $r 1, r 1,1 \quad ; i+$

j Loop

Exit:

Finish: $\quad ; * \star *$ end

trap

Aplikasi ini memerlukan 75 cycletime dengan jumlah instruksi yang dieksekusi 50 instruksi.

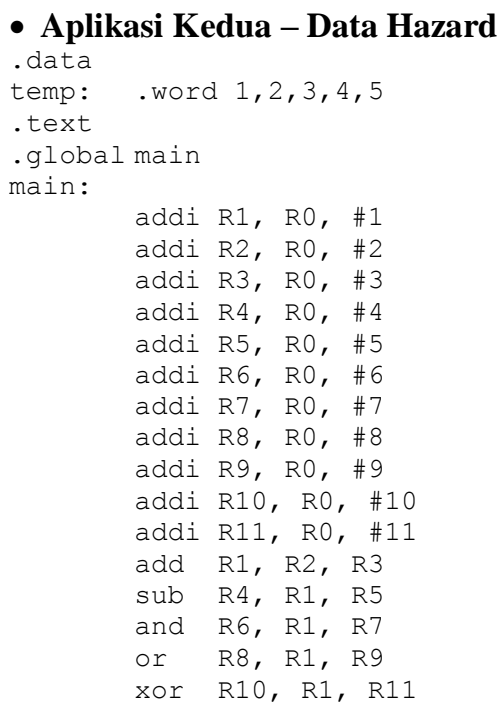




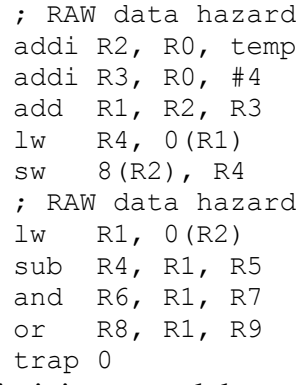

Aplikasi ini memerlukan 32 cycletime dengan jumlah instruksi yang dieksekusi 26 instruksi.

\section{- Aplikasi Ketiga - Tabel Bilangan Prima}

- data

-global Count

Count:

.word 10

-global Table

Table:

. space Count*4

. text

-global main

main:

\begin{tabular}{|c|c|c|}
\hline & $\begin{array}{l}\text { addi } \\
\text { addi }\end{array}$ & $\begin{array}{l}r 1, r 0,0 \\
r 2, r 0,2\end{array}$ \\
\hline \multicolumn{3}{|c|}{ NextValue: } \\
\hline & addi & $r 3, r 0,0$ \\
\hline \multirow[t]{9}{*}{ Loop: } & seq & $r 4, r 1, r 3$ \\
\hline & bnez & r4, IsPrim \\
\hline & $1 \mathrm{w}$ & r5, Table (R3) \\
\hline & divu & $r 6, r 2, r 5$ \\
\hline & multu & $r 7, r 6, r 5$ \\
\hline & subu & $r 8, r 2, r 7$ \\
\hline & beqz & r8, IsNoPrim \\
\hline & addi & $r 3, r 3,4$ \\
\hline & j & Loop \\
\hline \multicolumn{3}{|c|}{ IsPrim: } \\
\hline & Sw & Table $(r 1), r 2$ \\
\hline & addi & $r 1, r 1,4$ \\
\hline & $1 \mathrm{w}$ & r9, Count \\
\hline & srli & $r 10, r 1,2$ \\
\hline & sge & $r 11, r 10, r 9$ \\
\hline & bnez & r11,Finish \\
\hline \multicolumn{3}{|c|}{ IsNoPrim: } \\
\hline & $\operatorname{addi}$ & $r 2, r 2,1$ \\
\hline & j & NextValue \\
\hline \multicolumn{3}{|c|}{ Finish: } \\
\hline & rap & 0 \\
\hline
\end{tabular}

Aplikasi ini memerlukan 2605 cycletime dengan jumlah instruksi yang dieksekusi 750 instruksi.

- Aplikasi Keempat - Penjumlahan Nilai Skalar

Loop : LD F0, O (R1)

$$
\begin{aligned}
& \text { ADDD F4, F0, F2 } \\
& \text { SD } 0 \text { (R1), F4 } \\
& \text { SUBI R1, R1, } 8 \\
& \text { BNEZ R1, Loop }
\end{aligned}
$$

Analisis dengan memperhatikan Hazard dan melakukan stall pipeline :

Loop : LD F0,0 (R1)

$$
\text { Stall }
$$$$
\text { ADDD F4, F0, F2 }
$$

Stall

Stall

SD $0(R 1), F 4$

SUBI R1, R1, 8

BNEZ R1, Loop

Stall

Waktu yang diperlukan adalah 9 clock cycle.
Penjadwalan ulang program di atas menyebabkan perbaikan sebagai berikut:

Loop : LD F0, O (R1)

Stall
ADDD F4, F0, F2
SUBI R1, R1, \#8
BNEZ R1, LOOP
SD 8 (R1), F4

diperlukan 6 cycletime, jumlah instruksi 5.

- Aplikasi Kelima - Memori

Loop : LD F0, O(R1)

ADDD F4, F0, F2

$\mathrm{SD} 0(\mathrm{R} 1), \mathrm{F} 4$

LD $\mathrm{F} 6,-8(\mathrm{R} 1)$

ADDD F8, F6, F2

$\mathrm{SD}-8(\mathrm{R} 1), \mathrm{F} 8$

LD F10, -16 (R1)

ADDD F12, F10, F2

SD -16 (R1), F12

LD F14, -24 (R1)

ADDD F16, F14, F2

SD -24(R1), F16

SUBI R1, R1, \#32

BNEZ R1, LOOP

Analisis dengan memperhatikan Hazard dan melakukan stall pipeline :

Loop : LD F0, O(R1)

Stall

ADDD F4, F0, F2

Stall

Stall

$\mathrm{SD} 0(\mathrm{R} 1), \mathrm{F} 4$

LD $F 6,-8(R 1)$

Stall

ADDD F8, F6, F2

Stall

Stall

$\mathrm{SD}-8(\mathrm{R} 1), \mathrm{F} 8$

LD F10, -16 (R1)

Stall

ADDD F12, F10, F2

Stall

Stall

SD -16 (R1), F12

LD F14, -24 (R1)

Stall

ADDD F16, F14, F2

Stall

Stall

$\mathrm{SD}-24(\mathrm{R} 1), \mathrm{F} 16$

SUBI R1, R1, \#32

BNEZ R1, LOOP

Stall

Waktu yang diperlukan adalah 27 clock cycle.

Setelah dilakukan penjadwalan:

Loop : LD F0, $0(\mathrm{R} 1)$

$$
\begin{aligned}
& \text { LD F6, }-8 \text { (R1) } \\
& \text { LD F10, }-16(\mathrm{R} 1) \\
& \text { LD F14, }-24 \text { (R1) } \\
& \text { ADDD F4, F0, F2 } \\
& \text { ADDD F8, F6, F2 } \\
& \text { ADDD F12, F10, F2 } \\
& \text { ADDD F16, F14, F2 } \\
& \text { SD } 0 \text { (R1), F4 } \\
& \text { SD -8(R1), F8 } \\
& \text { SD -16(R1), F12 } \\
& \text { SUBI R1, R1, \#32 } \\
& \text { BNEZ R1, LOOP } \\
& \text { SD 8 (R1), F16 }
\end{aligned}
$$

Waktu yang diperlukan adalah 14 clock cycle, jumlah instruksi 14 . 


\subsection{Hasil Simulasi}

Hasil pengujian dari simulasi di atas ditunjukkan pada Tabel 3 di bawah ini.

Tabel 3. Hasil Pengujian

\begin{tabular}{|c|c|c|c|}
\hline Program & $\begin{array}{c}\text { E Cycle } \\
\text { Non Pipeline }\end{array}$ & $\begin{array}{c}\text { ECycle } \\
\text { Pipeline }\end{array}$ & Speedup \\
\hline Aplikasi 1 & 250 & 75 & 3,33 \\
\hline Aplikasi 2 & 130 & 32 & 4,06 \\
\hline Aplikasi 3 & 3750 & 2605 & 1,44 \\
\hline Aplikasi 4 & 25 & 6 & 4,11 \\
\hline Aplikasi 5 & 70 & 14 & 5 \\
\hline \multicolumn{2}{|c|}{ Rata-rata peningkatan kecepatan } & 3,59 \\
\hline
\end{tabular}

\subsection{Analisis Kinerja Prosesor DLX dengan Penerapan Pipeline.}

Dari Tabel 3 di atas dapat diamati bahwa seluruh aplikasi yang dijalankan dengan menggunakan simulator DLX Pipeline menunjukan peningkatan kinerja $1-5$ kali, dengan rata-rata peningkatan secara keseluruhan 3,59 kali. Ini membuktikan peningkatan kinerja yang signifikan dari penerapan metode Pipeline pada prosesor DLX.

Asumsi dasar menyatakan bahwa peningkatan kinerja menggunakan metode Pipeline dapat mencapai maksimal $=$ jumlah tahapan yaitu 5 . Dalam ujicoba ini terlihat bahwa yang sesuai dengan asumsi tersebut adalah Aplikasi 5 yang di dalamnya tidak terdapat stall. Sedangkan pipeline stall terjadi pada Aplikasi 1 sampai Aplikasi 4, yaitu siklus clock tambahan karena terdapat dua tahap yang memerlukan resource yang sama. Semakin banyak stall, peningkatan kecepatan prosesor DLX semakin turun. Pengujian pada Aplikasi 3, dengan stall terbanyak, menghasilkan peningkatan performansi sistem paling rendah, yaitu hanya 1,44 kali dari kondisi tanpa pipeline.

\section{Kesimpulan dan Saran}

\subsection{Kesimpulan}

1. Penerapan metode Pipeline pada prosesor DLX telah meningkatkan performansi sistem sampai 3,59 kali dari kondisi tanpa pipeline.

2. Peningkatan kinerja yang ideal adalah 5 sesuai dengan jumlah tahapan. Tidak tercapainya kondisi tersebut disebabkan oleh pipeline stall. Semakin banyak stall seperti, peningkatan kecepatan prosesor DLX semakin turun.

\subsection{Riset Selanjutnya}

Untuk mencapai kondisi ideal perlu diimplementasikan mekanisme penanganan Pipeline stall baik yang disebabkan oleh data hazard, struktur hazard atau control hazard.

\section{Daftar Pustaka}

[1] Adams, George, DLX View: A Window Simulator of DLX, Purdue University's School of Electrical and Computer Engineering.

[2] John L, Hennessy \& David A. Patterson, Computer Architecture A Quantitative Approach. Morgan Kaufmann Publisher, Ind. San Mateo. USA.

[3] Khosravipour, Maizar, Windows - DLX Simulator, Univ. of Technology Vienna. 1992.

[4] Larry, B. Hostetler \& Brian Mirtich, DLXsim a Simulator for DLX.

http://hardy.ocs.mq.edu.au/mpce_course/dlxsim /report.html

\section{Lampiran}

\section{Set Instruksi pada Prosesor DLX}

1. $\mathrm{ADD}: \operatorname{add}(\mathrm{R}-0 \times 20), \mathrm{Rt}=\mathrm{Rs} 1+\mathrm{Rs} 2$

2. ADDI : add immediate $(I-0 \times 80)$, Rt $=R s I$ + extend (Immediate)

3. AND : and $(\mathrm{R}-0 \times 24), \mathrm{Rt}=\mathrm{Rs} 1 \& \mathrm{Rs} 2$

4. ANDI : and immediate, $(\mathrm{I}-0 \mathrm{x} 0 \mathrm{C}), \mathrm{Rt}=$ Rs1 \& immediate.

5. BEQZ : branch if equal to zero, (I$0 \times 04), \quad P C+=(\operatorname{Rs} 1==0$ ? extend (immediate $): 0)$

6. BNEZ : branch if not equal to zero,

7. $(\mathrm{I}-0 \times 05), \mathrm{PC}+=(\mathrm{Rs} 1 \mathrm{!}=0$ ? Extend (immediate) :0)

8. J : jump, (J-0x02), PC+ = extend (nilai)

9. JAL : jump and link, (J-0x03), $\mathrm{R} 31=\mathrm{PC}+4 ; \mathrm{PC}=$ extend (nilai)

10. JALR : jump and link register, (I$0 \times 13), \mathrm{R} 31=\mathrm{PC}+4, \mathrm{PC}=\mathrm{Rs} 1$

11. JR : jump register, $(I-0 \times 12), P C=R s 1$

12. LHI : load high bits, (I-0x0f), Rt =immediate $<16$

13. LW : load word, $(I-0 \times 23)$, Rt $=$ Mem [Rs $1+$ extend (immediate) ]

14. OR : or, $(\mathrm{R}-0 \times 25), \mathrm{Rt}=\mathrm{Rs} 1 \mid \mathrm{Rs} 2$

15. ORI : or immediate, $(\mathrm{I}-0 \times 0 \mathrm{~d}), \mathrm{Rt}=\mathrm{Rs} 1$ I immediate

16. $\mathrm{SEQ}$ : set if equal, $(\mathrm{R}-0 \times 28), \mathrm{Rt}=(\mathrm{Rs}$ $==\operatorname{Rs} 2$ ? 1 : 0

17. SEQI : set if equal to immediate, (I$0 \times 18)$, Rt $=($ Rs $1==$ extend (immediate) ? $1: 0)$

18. SLE : shift left if less than or equal, $(\mathrm{R}-0 \times 2 \mathrm{C}), \mathrm{Rt}=(\mathrm{Rs} 1<=\mathrm{Rs} 2$ ? $1: 0)$ 
19. SLEI : shift left if less than immediate, (I-0X1C),

$\mathrm{Rt}=(\mathrm{Rs} 1<=$ extend (immediate) $) 1: 0$

20. SLL : shift left logical, (R-0x04), Rt $=$ Rs1 $<<($ Rs2 \% 8)

21. SLLI : shift left logical immediate, $(\mathrm{I}-0 \times 14), \mathrm{Rt}=\mathrm{Rs} 1<($ immediate $\% 8)$

22. SLT : set if less than, $(\mathrm{R}-0 \times 2 \mathrm{a}), \mathrm{Rt}=$ (Rs1<Rs2 ? 1: 0 )

23. SLTI : set if less than immediate, (I$0 \times 1 a)$, Rt $=($ Rs $1<$ extend (immediate) ? $1: 0)$

24. SNE : set if not equal, $(\mathrm{R}-0 \times 29), \mathrm{Rt}=$ $(\operatorname{Rs} 1 !=\operatorname{Rs} 2$ ? 1 : 0$)$

25. SNEI : set if not equal to immediate, (I-0x19), Rt $=($ Rs $1 !=$ extend (immediate) $? 1$ 0)

26. SRA : shift right arithmetic, as SRL \& see below

27. SRAI : shift right arithmetic immediate, as SRLI and see below

28. SRL : shift right logical, $(\mathrm{R}-0 \times 06)$, Rt $=\operatorname{Rs} 1>(\operatorname{Rs} 2 \% 8)$

29. SRLI : shift right logical immediate, $(\mathrm{I}-0 \times 16), \mathrm{Rt}=\mathrm{Rs} 1>($ immediate $\%$ 8)

30. SUB : substract, $(\mathrm{R}-0 \times 22)$, Rt $=\mathrm{Rs} 1-$ Rs2

31. SUBI : substract immediate, (I-0x0a), Rt $=$ Rs1 - extend (immediate)

32. SW : store word, $(I-0 \times 2 b)$, Mem [Rs $1+$ extend(immediate) ] $=\mathrm{Rd}$

33. XOR : exclusive or, $(\mathrm{R}-0 \times 26)$, Rt $=$ Rs 1^Rs2

34. XORI : exclusive or immediate, (IOx(e), $\mathrm{Rt}=\mathrm{Rs} 1 \wedge$ immediate.

Catatan:

- JAL dan JALR menggunakan Rsl saja, nilai immediate dan Rt dibuang.

SHI dipakai untuk mengambil bit-bit sebelah atas dari konstanta 32-bit.

- SRA dan SRAI adalah penggeseran kanan aritmetik. Bit tanda operand akan digandakan, bukan menggantinya dengan nol. SRL dan SRA akan sama jika Rs 1 bernilai positif. Jika Rsl negatif (bit $31==1)$, maka 1 disisipkan dari kiri untuk SRA dan SRAI.

- SW menggunakan Rt untuk register sumber (nilai yang disimpan di memori berasal dari Rt). 